\title{
The Role of Productive Structures in the Attractiveness of African Economies: A “Lucas Paradox" Approach
}

\author{
Honoré Bidiasse1, Michael Mbanjo Kitimbi', Marcelin Ndong Ntah² \\ ${ }^{1}$ Research Group in Economics and Management (GREG), University of Douala, Douala, Cameroon \\ ${ }^{2}$ African Development Bank, Nouakchott, Mauritania \\ Email: honobid72@gmail.com,michaelmbanjo@gmail.com,ndongntah@gmail.com
}

How to cite this paper: Bidiasse, $\mathrm{H}$., Mbanjo Kitimbi, M. and Ndong Ntah, M. (2019) The Role of Productive Structures in the Attractiveness of African Economies: A "Lucas Paradox" Approach. Modern Economy, 10, 1613-1632.

https://doi.org/10.4236/me.2019.106106

Received: April 23, 2019

Accepted: June 27, 2019

Published: June 30, 2019

Copyright $\odot 2019$ by author(s) and Scientific Research Publishing Inc. This work is licensed under the Creative Commons Attribution International License (CC BY 4.0).

http://creativecommons.org/licenses/by/4.0/

\begin{abstract}
The purpose of this article is to analyze the paradox of atrophy of capital flows to African countries, while economic theories predict that such flows of investment should be large enough because of higher returns on capital in countries where its presence is relatively low in production factors. The GMM estimate of a system of two equations for a sample of 25 African countries over the period 2004-2014 gives the following results: the low investment flows are due to the production structures of African economies, which lack efficiency and attractiveness. Also, by improving the structural elements of the economy that render production ineffective, African countries can thus increase their potential to raise larger flows of foreign direct investment.
\end{abstract}

\section{Keywords}

Foreign Direct Investment, Total Factor Productivity, GMM-System

\section{Introduction}

In line with the principle of declining marginal productivity, so dear to neoclassical theory, capital must migrate from the industrialized countries where it is abundant, to the developing countries where it is scarce and where its remuneration is consequently higher. In this context, low-income countries should not have particular difficulties in financing their development projects. But it is clear that developing countries in general and those in Africa in particular have difficulties in attracting foreign direct investment (FDI): this phenomenon is not new, it is the famous paradox of Lucas [1]. Moreover, well before Lucas and criticizing the theory of HOS, Wassily Leontief [2] had already "thrown a pavement 
in the fed up", questioning empirically the theory of the proportion of factors, as explanation of international exchanges.

According to United Nations Conference on Trade and Development (UNCTAD), in 2012, when Africa reached a peak in attractiveness with more than $\$ 77$ billion in FDI received, this amount accounted for only $4.8 \%$ of global flows. This disproportion, to the detriment of Africa in particular, is harmful for the financing of investments in this continent, especially since, as Kose et al. [3] through the "collateral benefits" effect, capital flows also have indirect effects on domestic investment.

Although Lucas' paradox has been the subject of an abundant literature to date, it has given rise to two main approaches. The first, supported by Lucas [1] and Alfaro [4], considers differences in the fundamentals of economies, such as the heterogeneity of factors of production and the quality of institutions, as the reason for this paradox. In contrast, the approach advocated by Reinhart and Rogoff [5], among others, highlights the weaknesses of capital markets, such as information asymmetry and sovereign risk, as major determinants of FDI.

But despite this fertile literature, some aspects of this paradox remain unexplored. First of all, the works cited above very often consider the sharing of a common technology. In other words, countries face the same local conditions of production of goods and services. However, the shortcomings of productive structures, characteristic of African economies, can affect the ability of economies to effectively combine the factors of production, which can contribute to reducing the productivity of capital and consequently its profitability. It must be said that the poor quality of transport infrastructure can make it difficult or impossible to get products to the consumer. However, the development and regular maintenance of infrastructure in an economy can be a source of reduced transaction and production costs. In this case, the production system is getting closer to efficiency, which favors the attractiveness of this economy. Moreover, as $\mathrm{Mu}-$ chielli [6] points out, the size of the market is one of the determinants of the establishment of a production unit. Also, a relatively small market size may limit the possibility of achieving economies of scale and thus constitute an inhibiting factor of attractiveness. In addition, it is increasingly recognized that information and communication technology (ICT) plays a major role in the attractiveness of FDI. According to the International Telecommunication Union (ITU) [7], Africa has an ICT development index of 2.48 points, barely half of Europe with 7.35 points. This low ICT penetration makes coordination between all actors in the production process less efficient.

Therefore, the purpose of this article is to determine the role of the structures of African economies on the attractiveness of foreign direct investment. Specifically, this is on the one hand to determine whether total factor productivity improves the attractiveness of African economies vis-à-vis FDI and, secondly, to evaluate the influence of each component of structural characteristics on total factor productivity. This approach has the advantage of identifying the channel through which structural characteristics affect the attractiveness of economies 
relative to FDI flows. Indeed, local conditions can affect attractiveness by making productivity. It is then necessary to show, firstly, that attractiveness depends on the overall productivity of the factors and then to determine the factors that affect this productivity.

To achieve this dual objective, this article uses an econometric methodology based on a two-stage model. The first, based on Alfaro et al. [8], measures the impact of Total Factor Productivity (TFP) on the inflow of foreign direct investment; the second floor starts from Jajri [9] to examine the influence of the structural features of economies on TFP. In this perspective, the chosen model is a system of simultaneous equations. However, their estimation poses some problems, two of which are major. Firstly, the temporal dimension, which is rather weak because of a decline of only ten years. Secondly, there is work that argues that FDI can boost TFP growth, thanks to the externalities of technology diffusion. This is obviously a problem of double causality. To correct this inverse causality, we apply the estimation by the so-called generalized moment's method (GMM), which has the merit of correcting the endogeneity of the explanatory variables of interest and other explanatory variables, especially for small panels whose temporal dimension is small compared to the number of individuals.

For the rest of the article, Section 2 makes a statistical analysis of FDI flows. Section 3 presents a review of the literature on the determinants of FDI. Section 4 describes [10] the methodology and presents the data used. The results and their analysis are discussed in Section 5 and Section 6 concludes.

\section{Statistical Analysis of FDI Flows}

\subsection{Analysis of the Temporal Evolution of FDI Flows}

FDI flows have steadily increased between 1980 and 1990. In fact, from 208 billion dollars in 1990, the amount of FDI will peak at 1400 billion dollars in 2000. Subsequently, the amount of FDI will is heavily contracted following the bursting of the bubble on new technologies: $\$ 825$ billion in 2001, and $\$ 566$ billion in 2003.

Despite the recovery that followed the year 2003 (Figure 1), the global financial crisis of 2007-2008 resulted in a further decline in global FDI flows, with a $31 \%$ fall in 2009. Despite the continuing consequences of the crisis, Global FDI inflows rose to $\$ 1770$ billion in 2015 , before falling back to $\$ 1740$ billion in 2016 , however, with different regimes in different parts of the world.

\subsection{Analysis of the Distribution of FDI around the World}

The analysis of the distribution of FDI flows shows that developed economies are the preferred destination for FDI over time, even if their attractiveness has been somewhat eroded. More specifically, Figure 1 shows that between 1995 and 2016, developing countries received between $15 \%$ and $34 \%$ of FDI inflows, while developed countries had most of these flows ranging from $43 \%$ to at $83 \%$. But the distribution of FDI flows between developing economies itself is far from 


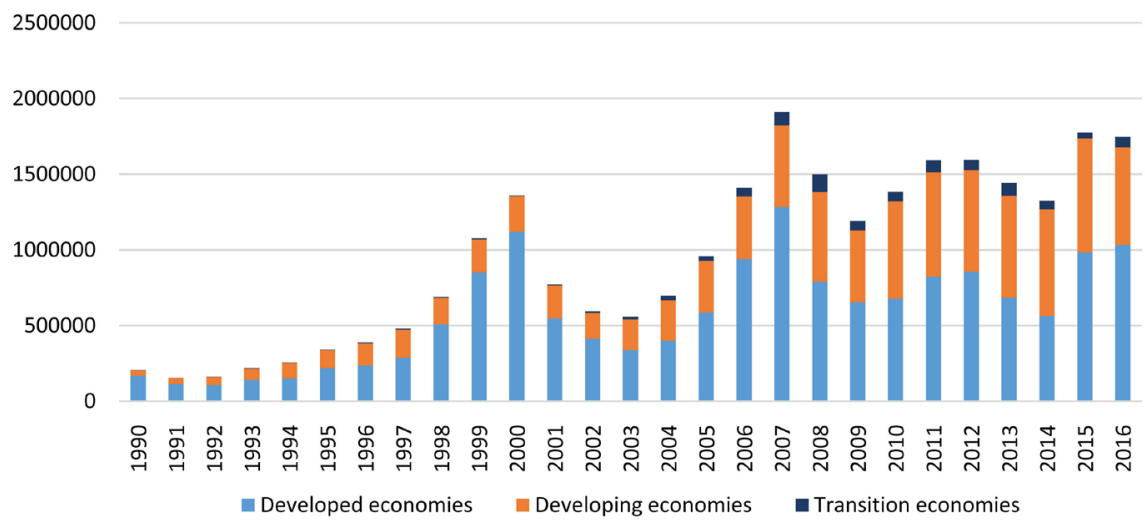

Figure 1. Evolution of global FDI flows by region. Source: Authors, based on UNCTAD data.

uniform. Since the 1990s, developing countries in Asia have consistently received most FDI to developing economies, while Africa has been the least attractive region.

Africa's share of world flows has been stable, although the reading of this progression can be analyzed in two phases. A first where flows go from close to $10 \%$ to less than $1 \%$ in 1980 . Then the second phase where the influx of capital rises to stabilize at an average around $3 \%$ until 2013. The process of globalization that was developing at that time left Africa behind. The share of African economies in the flows of developing countries is also falling, it has remained below $10 \%$.

While Asia grew from 22 billion inflows in 1990, to a peak of more than 430 billion US dollars in 2011, an increase of 408 billion, the African rose from 2 billion US dollars to 57 billions of dollars over the same period, an increase of 55 billion, which corresponds to only $13.48 \%$ of the increase of flows towards Asia. It must be said that this volume appears relatively small, compared to the performance of Asia and given the context of globalization.

This limited influx of investment in developing countries in general (Figure 2 ), while these countries are characterized by the scarcity of capital, has sparked a great deal of research in order to explain the reasons for the paradox.

\section{Literature Review}

Two main explanatory approaches emerge to explain the "Lucas paradox". The first approach concerns differences in the fundamentals of economies. More specifically, these are factors affecting total factor productivity, such as the heterogeneity of factors of production and the institutional structure [Lucas (1990) [1] and Alfaro (2003) [4]].

The second approach, advocated mainly by Reinhart and Rogoff (2004) [5] and Portes and Rey (2005) [10], is based on the imperfections of international capital markets, such as asymmetric information and funding frictions.

With regard to human capital, Lucas (1990) [1] shows, in a theoretical study between India and the United States, that India has a productivity 58 times higher than that of the United States. But taking into account the heterogeneity 


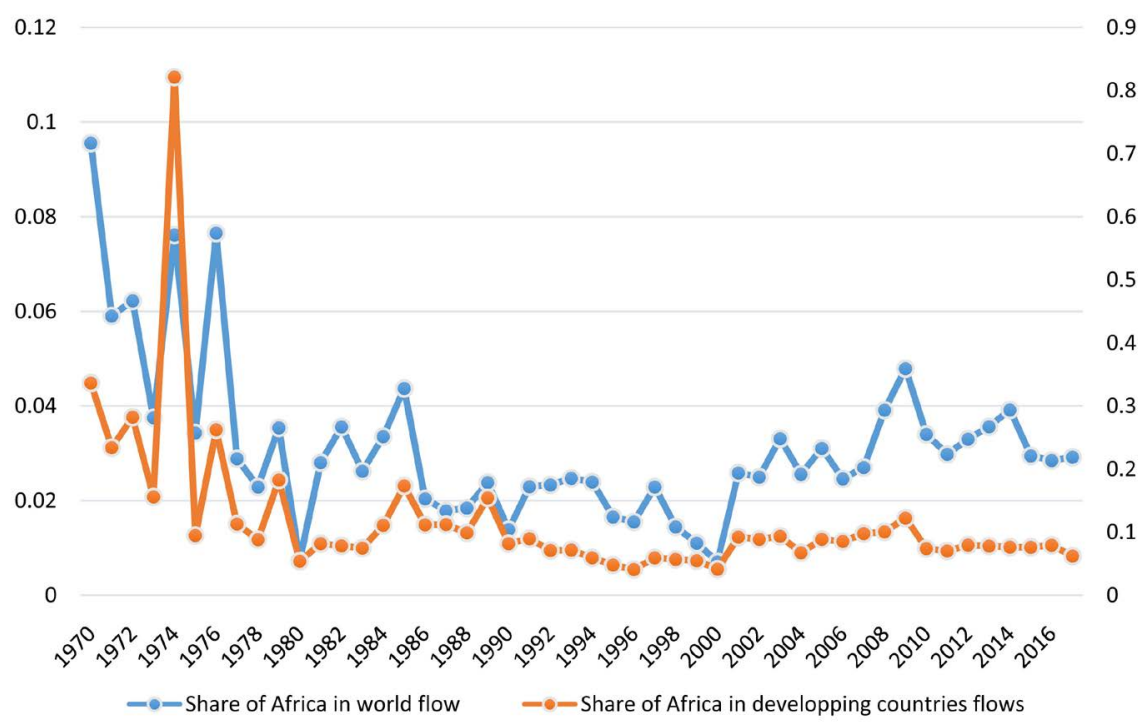

Figure 2. Share of Africa in FDI flows. Source: Authors, based on UNCTAD data.

of the factors and the externalities it generates eliminates this productivity gap. Indeed, human capital can make a significant contribution to the ability to adapt and implement new, more productive technologies. Similarly, in the context of the use of existing technologies, capital productivity may also depend on human capital in the broad sense, that is, not only literacy and other aspects of education, but also the industrial experience. However, for Darreau and Pigalle (2008) [11], the human capital productivity gaps obtained by Lucas (1990) [1] are quite unrealistic in order to be able to retain the unique hypothesis of differences in terms of human capital endowment. Other factors such as institutions will emerge to explain this state of affairs.

North (1991) [12] defines the institutions of a society as the set of rules of the game. These rules shape the relationships between companies and provide an essential framework for an agent to enter into transactions. A suitable institutional environment would reduce transaction costs [Williamson (1975) [13] and Williamson (1985) [14]]. Nielsen et al. (2017) [15] note that the literature focuses primarily on the additional risks and costs of performing certain economic activities in territories characterized by poor institutions. Thus, the poor quality of institutions affects the attractiveness of low-income countries, where property rights are not always respected, corruption is endemic, revolutions, coups and expropriations are more frequent.

Also, the results of authors such as Alfaro et al. (2003) [4] corroborate these intuitions and show that institutional weaknesses create a gap between expected returns and actual returns. While technology is easily accessible to all countries, barriers to adoption or differences in the effective use of technology can significantly change the return on capital. In such a case, the equalization of returns does not necessarily imply capital flows from rich to poor countries. Later work by Alfaro (2008) [4] reveals that the quality of institutions is the main causal variable explaining the Lucas paradox. 
But for Azemar et al. (2013) [16], these empirical works are controversial. First, the quality of institutions is inherently difficult to measure. According to the author, many cross-sectional studies ignore important fixed country effects, panel data would not allow to measure the impact of institutions, in light of the small variation over time. Second, the sense of causality is uncertain: although good quality institutions can encourage capital flows, they can also foster institutional development. Third, the mechanism by which institutions affect capital flows is often unknown. Therefore, the imperfections of the capital markets can be another way to explain the paradox of Lucas.

The main explanations for the imperfection approach in international capital markets are information asymmetry and sovereign risk [Reinhart (2004) [5]; Rogoff and Gertler (1990) [17]]. According to Montiel (2006) [18], the paradigm of the simple neoclassical growth model assumes an absence of informational frictions that can hinder investment. However, the asymmetry of information is deemed to significantly hinder the execution of financial transactions by driving up their cost. Clearly, it is not enough that there are opportunities for productive investment on the continent, it is also necessary that potential external creditors be informed.

The work of Ahearne et al. (2004) [19] show that the poor quality and low credibility of financial information in foreign countries has strong explanatory power over the lack of capital flows to poor countries. Vasileva (2008) [20] goes on to say that investors prefer to invest in countries near their country of origin, or countries of the same economic union or with a similar legal system. They feel more optimistic and confident in investing in the most familiar countries because of informational benefits, despite potentially more attractive returns from developing countries.

African countries do not have a well-developed financial system that can play an effective intermediary role between domestic and foreign private creditors on the one hand, and domestic private enterprises on the other, resulting in significant external financing premium. Mendoza et al. (2009) [21] explicitly associate financial development with the ability to enforce financial commitments. A more sophisticated financial sector can simply facilitate international transactions. It can also lead to better capital allocation, thereby increasing marginal marginal productivity.

Odedokun (2003) [22], however, estimates a positive development impact of the financial sector on all capital flows, including FDI. The same is true of the more recent study by Djahini (2015) [23], which shows that the development of the financial system plays a positive role in the attractiveness of FDI of African economies. Rancière et al. (2008) [24] argue that some of the contradictory results can be attributed to the fact that financial development promotes growth but also makes a country more vulnerable to crises.

The risk associated with the host country is also an important factor. Indeed, the risk is deemed to increase the cost of investments and uncertainty: even if the private return is expected to be high, a large amount of uncertainty surrounding 
the expropriation can be unacceptable. Whether for Gertler and Rogoff (1990) [17] or for Reinhart and Rogoff (2004) [5], episodes of default in the past are the key explanation for the low volume of capital inflows to poor countries. Capital would thus remain in rich countries, even if the theoretical investment opportunities are far from exhausted in poor countries.

Odedokun (2003) [22] notes that external public debt discourages foreign investors, suggesting that fear of future taxes acts as a deterrent. In the framework of West African Economic and Monetary Union (WAEMU), Koudou (2014) [25] shows that in the short term, the external debt of one year has a statistically significant impact on the variation of the net inflow of FDI of the following year. This implies that better risk sharing facilitates the financing of investment projects. For Faria et al. (2004) [26], portfolio investment and debt are positively correlated with financial development.

Nevertheless, information frictions are only one explanation among others, not necessarily the most convincing. Because, the works evoked until then have not taken very much into account the difficulties relating to the appropriation of the new technologies and the process of production by the developing economies. These difficulties of ownership can lead to technologies being accessible to African economies being less productive than those of creditor countries. Indeed, according to Eichengreen (2003) [27] cited by Alfaro et al (2008) [4], capital-labor ratios in different countries could diverge due to differences in cultural context and/or technological capacity. Prescott (1998) [28] goes on to explain that while technologies are similar across countries, the effective use of existing technologies or reluctance to adopt new production technologies depends on an economy's ability to combine to produce more.

At the same time, the productive structures of African economies are reputed to be failing. First, ICT development in Africa is still embryonic with an ICT Development Index (IDI) of 2.48, while Europe ranks first with 7.35. In addition, the poor quality of transport infrastructure is garish: only $29 \%$ of roads are asphalted compared to $44 \%$ for middle-income countries. In Central Africa, less than $15 \%$ of the road network is asphalted. Finally, new high-efficiency technologies sometimes involve large-scale production. In such cases, the small size of the economies, the persistence of trade barriers, as well as the infrastructural deficiencies mentioned above may limit the scope of the market and thus hinder efficient production.

In total, the structural factors of an economy can affect the efficiency of the productive system and reduce the profitability of investments. This will ultimately lead to a reorientation of the destination of investments. It is then necessary to build an evaluative approach of the role of the structures of the economies on their attractiveness vis-à-vis FDI.

\section{Methodology}

The methodological approach adopted is presented in three stages: first, the 
presentation of the empirical model; then the justification of the choice of the estimation method and finally the presentation of the data.

\subsection{Empirical Model}

The work on the explanation of the Lucas paradox is generally based on a Cobb-Douglas production function, assumed to have constant returns. In addition, the assumption of free movement of factors of production is retained. In this context, considering two countries producing the same good, the decrease in the marginal productivity of capital and the direction of corresponding investment flows can be approached from Equations (1) and (2).

$$
Y_{t}=A_{t} F\left(K_{t}, L_{t}\right)=A_{t} K_{t}^{\alpha} L_{t}^{1-\alpha}, F^{\prime}(.)>0, F^{\prime \prime}(.)>0, F(0)=0
$$

where $Y$ is production and $A$ is the productivity parameter, $K$ and $L$ are respectively capital and labor and $\alpha$, the share of capital in income.

This model predicts that capital should migrate freely from rich to poor countries until marginal returns are equal between these two groups of countries.

Therefore, for countries $i$ and $j$,

$$
A_{t} f^{\prime}\left(k_{i t}\right)=r_{t}=A_{t} f^{\prime}\left(k_{j t}\right)
$$

Lucas (1990) [1], in considering the existence of capital flows to poor countries, shows that they are well below their level predicted by neoclassical theory. This could explain why the return on investment in Africa is not high compared to that obtained in these rich countries.

This gap between theoretical profitability and actual profitability of capital could be explained by the fact that the structural features of economies hinder the adoption and/or efficient use of technology, which results in lower capital productivity and, in turn, fine, to a limited attractiveness. Prescott (1998) [28] argues that effective use of existing technologies or reluctance to adopt new ones depends on the "combination" that a society holds for them-the ability to better combine same amounts of capital and labor to produce more. In these conditions, marginal capital returns are evenly spread across countries, without converging capital levels per capita. This difference is explained by the fact that production is more efficient in rich than in poor countries because of local production conditions and the level of productivity associated with it.

So for two countries $i$ and $j$, the equalization of the yield is given by:

$$
A_{i t} f^{\prime}\left(k_{i t}\right)=r_{t}=A_{j t} f^{\prime}\left(k_{j t}\right) \text { Avec } k_{i t} \neq k_{j t}
$$

In order to achieve this dual objective, this article uses an econometric methodology based on a two-stage model. The first, based on the Alfaro et al (2003) [4] specification, measures the impact of TFP on the inflow of foreign direct investment; the second floor is based on Jajri (2007) [9] to examine the influence of structural features of economies on total factor productivity.

This choice is justified by the fact that the intrinsic structural factors of an economy can constitute obstacles to FDI flows, passing through the TFP. In the 
case of African countries, characterized by small economies, the low ICT use and the shortcomings of the transport network, by reducing the efficiency of the productive combination, are likely to reduce the profitability of the investments compared to the yield found in continents that have more efficient structures. In the case of Africa, this implies, for a rational investor, a reorientation of the destination of his investments. This leads to the specification below:

$$
\begin{aligned}
T F P_{i t}= & \gamma_{i}+\delta_{1} Q T I_{i t}+\delta_{2} S_{2} Z_{i t}+\delta_{3} I c t_{i t}+\delta_{4} O P E_{i t} \\
& +\delta_{5} \operatorname{Cap}_{i t}+\delta_{6} I N V_{i t}+\epsilon_{i t} \\
L F D I_{i t}= & \alpha_{i}+\beta_{1} T F P_{i t}+\delta_{2} N R E S_{i t}+\beta_{3} H C_{i t}+\beta_{4} R P R_{i t} \\
& +\beta_{5} F D_{i t}+\beta_{6} G R O_{i t}+\beta_{7} I N F_{i t}+\varepsilon_{i t}
\end{aligned}
$$

\subsection{Source of Data and Preliminary Analyzes}

The data used come from four main sources: the World Development Indicators (WDI), the Penn World Table (PWT), the African Infrastructure Development Index (AIDI) and the World Governance Indicator (WGI) for institutional variables. Some variables required some preliminary transformation or calculations, such as the open rate. Table 1 below summarizes the model variables and the indicators used to capture the associated phenomena. The choice of a sample of 25 countries is explained exclusively by the availability of data on all the variables of the model. This explains why the different regions of Africa are unevenly represented. There are 15 countries in Central and West Africa, 2 in North Africa and 8 in Southern and Eastern Africa. Appendix Table A2 provides an exhaustive list.

It should be emphasized that the use of a regression model with a temporal dimension requires the need to ensure that each series involved in the modeling has good properties (stationarity), in order to guarantee unbiased inference.

In panel data, there are two generations of unit root tests in the literature (Dickey-Fuller, 1979) [29]. The first, supported by Madala and Wu (1999) [30], Choi (2001) [31], Levin and Lin (2002) [32], applies under the assumption of independence between panelists: factors common to countries are neglected (we can have the example of global growth). The second, [Choi (2002) [31], Chang (2002) [33], Pesaran (2003) [34], Moon and Perron (2004) [35] takes into account the dependence between individuals. This article retains the approach of Levin and Lin (2002) [32] and Pesaran (2003) [34], for which both types of tests are carried out, with the aim of analyzing interindividual independence.

From the results, most of the variables are stationary in level for both types of tests. Thus, even if there is interindividual dependence (Pesaran test, 2003) [34], linkage factors between individuals have no unit root. The ICT, OPE and LCAP variables are not stationary under the hypothesis of interindividual independence. But, taking into account the dependence, it is rather the variables QTI and ICT which are not it, they are integrated of order 1.

Since the theoretical model does not make any assumption about individual independence, we note the stationarity resulting from the Pesaran test (2003) 
Table 1. Variables overview and data source.

\begin{tabular}{|c|c|c|}
\hline Variables & Signification & Measure \\
\hline TFP & Total Factors Productivity & $\begin{array}{l}\text { TFP level knowing that the United States } \\
\text { is worth } 1 \text { (Penn World Table Base) }\end{array}$ \\
\hline LFDI & Foreign Direct Investment & $\begin{array}{l}\text { Logarithm of incoming FDI flows } \\
\text { (Base WDI), transformed by the formula: } \\
\text { FDI } 2=\frac{\text { FDI }+|\min (\mathrm{FDI})|}{2}+1 \\
\text { (In order to make them strictly positive) }\end{array}$ \\
\hline QTI & $\begin{array}{l}\text { Quality of Transport } \\
\text { Infrastructures }\end{array}$ & $\begin{array}{l}\text { Synthetic Index of the African } \\
\text { Infrastructure Development Index (AIDI) }\end{array}$ \\
\hline SIZ & Market size & Average income per capita (WDI basis) \\
\hline ICT & ICT use & $\begin{array}{l}\text { Percentage of people subscribed to } \\
\text { mobile telephony (WDI base) }\end{array}$ \\
\hline OPE & Opening of the economy & Measured by the report $(\mathrm{X}+\mathrm{I}) / \mathrm{GDP}$ \\
\hline CAP & Capital structure & $\begin{array}{c}\text { Measured by the ratio of } \\
\text { physical capital stock to GDP }\end{array}$ \\
\hline NRES & Natural resources & $\begin{array}{l}\text { Share of natural resources } \\
\text { in GDP (WDI basis) }\end{array}$ \\
\hline $\mathrm{HC}$ & Human capital & $\begin{array}{l}\text { Average number of years of study } \\
\text { (Penn World Table) }\end{array}$ \\
\hline RPR & Respect of property rights & WGI synthetic index \\
\hline FD & Financial development & $\begin{array}{l}\text { Credit volume as a percentage } \\
\text { of GDP based on WDI }\end{array}$ \\
\hline GRO & Rate of growth & GDP growth rate (WDI basis) \\
\hline INF & Rate of inflation & Rate of inflation ( WDI basis) \\
\hline INV & Rate of investissement & $\begin{array}{l}\text { Gross fixed capital formation } \\
\text { as a percentage of GDP (WDI basis) }\end{array}$ \\
\hline
\end{tabular}

Source: Authors.

[34], which takes into account interindividual dependence. This is why QTI and ICT variables are introduced into the differentiated form. We also studied the links with the differentiated values of non-stationary variables by the Levin and Lin (2002) [32] test, in order to be reassured of the optimality of the choice of modeling.

The analysis of the correlation matrix in the Appendix shows that the variables TFP and LCAP are correlated and strongly correlated with the variable LFDI $(r=0.52$ and $r=0.80)$. Similarly, the FD variable is correlated to FDI $(r=$ 0.46). In addition, the variables HC, QTI, LCAP and SIZ are strongly correlated with the variable TFP. The variables QTI, SIZ and FD are strongly correlated with the variable HC. We also noted a strong correlation between SIZ and FD on the one hand, LCAP and FD on the other hand. It then appears a problem of multicolinearity between the explanatory variables that should be corrected from an appropriate estimation method. 


\subsection{Estimation by the Method of Generalized Moments}

Given the literature review and the descriptive analyzes above, the estimation method chosen is that of generalized moments (GMM) on a dynamic panel. Indeed, the literature suggests the possibility for past values of an endogenous variable to influence the dynamics of future values of the explained variable. Baltagi (2012) [36] proposes the use of delayed values of the explained variable, or even other endogenous variables, as an explanatory variable in such a case. In addition, there are descriptive analyzes, a correlation between certain variables that can explain the evolution of FDI flows in Africa. This can be a source of autocorrelation of errors and also of heteroskedasticity. The general form of the model is therefore the following:

$$
L F D I_{i t}=\delta F D I_{i t-1}+X_{i t} \beta+u_{i t}, i=1, \cdots, N ; t=1, \cdots, T
$$

where $\delta$ is a constant, $\beta$ the vector $K \times 1$ of the coefficients corresponding to $K$ explanatory variables; $X_{i t}$ the matrix whose columns represent the explanatory variables of the model; $u_{i t}=\mu_{i}+\varepsilon_{i t}$ is the error term of a compound error model: $\mu_{i} \sim \operatorname{IID}\left(0, \sigma_{\mu}^{2}\right)$ is the country-specific error term $\mathrm{i}$ and $\varepsilon_{i t} \sim \operatorname{IID}\left(0, \sigma_{\varepsilon}^{2}\right)$ the term random error. The two terms of error are for each of them independent and identically distributed, and independent of each other.

Two sources of autocorrelation of errors are identified: autocorrelation due to the presence of delayed values of the dependent variable and the consequence of the presence of individual specific effects $\left(\mu_{i}\right)$, characterizing the heterogeneity between countries. One can also have problem of homoskedasticity of the errors. Unlike other methods capable of solving the aforementioned problems, the GMM method is more suitable for small panels, whose temporal dimension is small compared to the number of individuals. It is an extension of the simple instrumental variable estimation method in which one can have delayed values of endogenous variables as instruments. There are two variants of estimation by this method:

- The estimation of the first difference model with instrumental variables of Arellano and Bond (1991) [37], which makes it possible to cancel the effects specific to individuals.

$$
\Delta L F D I_{i t}=\delta \Delta L F D I_{i t-1}+\Delta X_{i t} \beta+\varepsilon_{i t}
$$

- The estimation of a system of two equations of Blundell and Bond (1998) [38], one in first difference and the other in level. The authors show by Monte Carlo simulation that the GMM estimator in the system is more efficient than that obtained in the first difference, because the latter gives biased results in finished samples when there are few valid instruments.

$$
\left\{\begin{array}{l}
\Delta L F D I_{i t}=\delta \Delta L F D I_{i t-1}+\Delta X_{i t} \beta+\Delta \varepsilon_{i t} \\
L F D I_{i t}=\delta L F D I_{i t-1}+X_{i t} \beta+\mu_{i}+\varepsilon_{i t}
\end{array}\right.
$$

The GMM estimate in system amounts to making a GMM estimate for a single equation on a database consisting of an online concatenation of the differentiated values of the variables on each individual (above) and the initial database 
(in below). The instruments in the first difference equations are expressed in level and the equations in level are expressed in first difference.

\section{Results and Analyzes}

As the methodological approach suggests, the presentation of the results will also be done in two stages: first, the results of the first stage of the model, which links the volume of FDI received to overall factor productivity; secondly, those of the second stage, relating to the impact of the structures of the economies on the total productivity of factors. However, the estimation of the model is done by distinguishing the case of all the countries in the sample from that of the Central and West Africa region. The results of the Maghreb and Southern and Eastern Africa regions are not presented because they do not have a sufficiently large number of observations to ensure the econometric validity of the estimates.

\subsection{The Effects of Total Factor Productivity on the Attractiveness of FDI}

Table 2 below presents the results of the estimation for all countries in the database. The results of the model validation tests yield the following results at the $5 \%$ threshold. Indeed, the results validate the hypotheses of no autocorrelation of orders 1 and 2. Similarly, the exogeneity tests of the instruments confirm that the instruments are exogenous. As for the Sargan and Hansen test, they confirm that all the instrumental variables are valid. Finally, the normality test for

Table 2. Result of TFP effects on the attractiveness of regions.

\begin{tabular}{|c|c|c|}
\hline FDI & Africa & Central and West Africa \\
\hline Constant & $\begin{array}{c}23.202^{* * *} \\
(0.000)\end{array}$ & $\begin{array}{c}22.423^{* * *} \\
(0.000)\end{array}$ \\
\hline Total Factors Productivity & $\begin{array}{l}5.463^{* *} \\
(0.031)\end{array}$ & $\begin{array}{c}3.551^{* * *} \\
(0.000)\end{array}$ \\
\hline Human Capital & $\begin{array}{c}-4.322^{* * *} \\
(0.006)\end{array}$ & $\begin{array}{c}-2.845^{\star *} \\
(0.012)\end{array}$ \\
\hline D_ICT use & $\begin{array}{l}0.591^{* *} \\
(0.012)\end{array}$ & $\begin{array}{c}0.346 \\
(0.020)\end{array}$ \\
\hline Inflation rate & $\begin{array}{c}0.192 \\
(0.037)\end{array}$ & $\begin{array}{l}0.054^{\star} \\
(0.184)\end{array}$ \\
\hline Observations & 250 & 150 \\
\hline Number of instruments & 9 & 9 \\
\hline $\operatorname{AR}(1)$ & 0.102 & 0.219 \\
\hline $\operatorname{AR}(2)$ & 0.360 & 0.919 \\
\hline Sargan test & 2.03 & 8.12 \\
\hline Probability test of Sargan & 0.730 & 0.087 \\
\hline Hansen test & 2.94 & 5.34 \\
\hline Probability test of Hansen & 0.568 & 0.254 \\
\hline
\end{tabular}

Source: the authors. Note: The p-values are indicated in parentheses; ${ }^{*},{ }^{*}$, and ${ }^{* *}$ indicate significance at the confidence level of $10 \%, 5 \%$, and $1 \%$ respectively. 
residues shows that country-specific residues and the term random error are normal.

The results of the estimations make it possible to retain 4 significant variables (TFP, HC, d_ICT, INF) capable of explaining the increase of FDI flows in Africa. Total factor productivity is the most favorable factor for increasing net FDI flows in Africa and the West and Central Africa sub region, which confirms the intuition of Prescott (1998) [28], as well as he extends the results of Piteli (2010) [39], which presented total factor productivity as a major determinant of FDI in developing countries. An increase of one unit of total factor productivity (TFP) contributes on average to a 5.5\% increase in net FDI inflows in Africa.

However, increasing the human capital of a unit reduces net inflows of FDI by an average of $4.3 \%$. This result, although in contradiction with most of the work (Cleeve, 2008) [40] on the effects of human capital on the influx of FDI, is confirmed both in Africa in general and in West and Central Africa. The result obtained can be justified by several arguments. Given that, on the one hand, most FDI in Africa is directed towards sectors requiring little qualified local labor, and on the other hand, human capital is here evaluated by the number of years of study. it can be expected that the more years an individual is studying, the less likely he is to be underemployed; and even if it were, its high wage claim would discourage foreign investors from hiring it, especially since they are interested in cheaper labor. Moreover, it can be assumed that educated people can be potential entrepreneurs and compete with foreign investors; As a result, they can block the flow of inward FDI or channel their investment abroad, reducing the net flow of FDI.

Differences in results between the global sample and that of Central and West Africa appear mainly on the role of ICT and inflation. On the sample in general, the increase in the number of ICT users in a country causes FDI inflows to grow by almost $0.60 \%$. In other words, the increase in the number of ICT users is accompanied by an increase in inward FDI flows compared to the previous year. This confirms Lee's (2016) [41] result on the positive effect of FDI diffusion on capital inflow, as ICT facilitates coordination of activities and reduces uncertainty. However, in West and Central Africa, this variable does not have a significant effect, although this effect goes in the same direction as in the global model.

In contrast, the role of macroeconomic stability, approximated by the rate of inflation, is a determinant of the attractiveness of FDI in West and Central Africa, but not in Africa in general. This can be explained by the fact that this variable plays a marginal role in the other regions. The results of Mhlanga et al. (2010) [42] show that the inflation rate has no effect on FDI flows in the Southern African Development Community (SADC) zone.

\subsection{The Explanatory Factors of the Evolution of Total Productivity in Africa}

To determine the factors that may explain changes in total factor productivity, 
we start with an estimate of the time averages. In addition to the correlation analysis, the inter-country estimate shows that, on average and over the study period, the change in total factor productivity is mainly due to the capital structure, the quality of transport infrastructure and the size of the economy. An increase in total factor productivity in Africa in general, all things being equal, stems from the growth of at least one of these variables. Thus, total factor productivity influences FDI inflows to Africa in a global way, through these factors (Table 3).

For West and Central Africa, the estimation results show that: if we omit the likely effects of past values of total factor productivity and country-specific characteristics, the capital structure and the size of the market factors that may explain a possible change in total factor productivity. Indeed, these two causes of autocorrelation make it necessary to estimate the model for the countries of Central and West Africa from the least generalized squares. The result is that an increase in total factor productivity results from a growth in the capital structure or the size of the economy.

These two steps show that structural factors that are specific to an economy may be obstacles to FDI flows to Africa through TFP. Indeed, the small size of the African economies and the shortcomings of the transport network, by reducing the efficiency of the productive combination, are likely to reduce the effective profitability of the investments, compared to the yields observed on the continents with more efficient structures. Reducing the return on investment in Africa means that a rational investor will have to reorient the destination of his investments, which helps to explain Lucas' paradox.

Table 3. Factors explaining the evolution of total productivity in Africa.

\begin{tabular}{ccc}
\hline TFP & Africa & Central and West Africa \\
\hline Constant & -0.372 & $-0.0161^{\star}$ \\
& $(0.225)$ & $(0.0895)$ \\
Ln(Capital structure) & $0.061^{\star *}$ & $0.0243^{* *}$ \\
& $(0.035)$ & $(0.042)$ \\
Quality of Transport Infrastructure & $0.059^{*}$ & \\
& $(0.036)$ & $0.0001^{* * *}$ \\
Market size & $0.00005^{* * *}$ & $(0.000)$ \\
& $(0.004)$ & 0.0683 \\
Openess & -3.239 & $(0.200)$ \\
& $(0.378)$ & \\
ICT use & -0.0291 & -0.001 \\
& $(0.476)$ & $(0.161)$ \\
Investment & 0.001 & \\
$\mathbf{R}^{2}$ & $(0.874)$ & $\mathbf{5 4 . 7 3}$ \\
Wald chi & & $\mathbf{0 . 0 0 0}$ \\
Prob chi & &
\end{tabular}

Source: the authors. Note: The p-values are indicated in parentheses; ${ }^{*},{ }^{* *}$, and ${ }^{* * *}$ indicate significance at the confidence level of $10 \%, 5 \%$, and $1 \%$ respectively. 


\section{Conclusions}

The purpose of this article was to determine the role of the structures of African economies on the attractiveness of foreign direct investment, i.e. specifically, on the one hand, to measure the impact of the total productivity of foreign direct investment factors on the attractiveness of African economies through FDI, and on the other hand, to assess the influence of each component of the structural characteristics on total factor productivity. The application of the generalized method of moments on a database of WDI, AIDI, PWT, WGI, made up of 25 African countries, gives some significant results.

It appears that both for Africa in general and for Central and West Africa, the Lucas paradox is explained by the fundamentals of economies that affect the ability of the economy to effectively combine its factors of production. In other words, the overall factor productivity is determined by the size of the economies, the capital structure and the quality of transport infrastructure for African economies in general. The first two factors are also significant for the economies of Central and West Africa.

Therefore, to improve the attractiveness of African countries for FDI, the recommendations go in the direction of building better transport and communication infrastructure, which would reduce transaction costs, because a reconciliation of companies with their customers and their suppliers. Moreover, the promotion of sub-regional integration and the development of cross-border transport infrastructures can prove to be a saving one, since it would lead to an increase in the size of the markets, and thus to an improvement of the attractiveness, investors being in constant search of outlets.

African economies need to invest more to improve their production structures to enhance the production efficiency and attract more FDI. The priority sectors identified are transport infrastructure and ICT use. In addition, it is good to encourage the development of free trade zones to increase the size of the markets accessible by multinational firms.

\section{Conflicts of Interest}

The authors declare no conflicts of interest regarding the publication of this paper.

\section{References}

[1] Lucas, R. (1990) Why Doesn't Capital Flow from Rich to Poor Countries? American Economic Review, 80, 92-96.

[2] Leontief, W. (1954) Domestic Production and Foreign Trade: The American Capital Position Re-Examined. Economia Internazionale, 3, 3-32.

[3] Kose, M., Prasad, E. and Terrones, M.E. (2006) How Do Trade and Financial Integration Affect the Relation between Growth and Volatility? Journal of International Economics, 69, 176-202. https://doi.org/10.1016/j.jinteco.2005.05.009

[4] Alfaro, L., Kalemli-Ozcan, S. and Volosovych, V. (2008) Why Doesn't Capital Flow from Rich to Poor Countries? An Empirical Investigation. The Review of Econom- 
ics and Statistics, 90, 347-368. https://doi.org/10.1162/rest.90.2.347

[5] Reinhart, C. and Rogoff, K. (2004) The Modern History of Exchange Rate. Quarterly Journal of Economics, 119, 1-48.

[6] Mucchielli, J.-L. (1998) Multinationales et mondialisation. Le Seuil, Paris.

[7] ITU (2016) Measuring the Information Society Report: Key Findings. Génève.

[8] Alfaro, L., Areendam, C., Kalemli-Ozcan, S. and Selin, S. (2003) FDI and Economic Growth: The Role of Local Financial Markets. Journal of International Economics, 61, 512-533. https://doi.org/10.2139/ssrn.305762

[9] Jajri, I. (2007) Determinants of Total Factor Productivity Growth in Malaysia. Journal of Economic Cooperation, 28, 41-58.

[10] Portes, R. and Rey, H. (2005) The Determinants of Cross-Border Equity Transaction Flows. Journal of International Economics, 65, 269-296. https://doi.org/10.1016/j.jinteco.2004.05.002

[11] Darreau, P. and Pigalle, F. (2008) Les paradoxes de Lucas et Romer. Revue Economique, 59, 843-851. https://doi.org/10.3917/reco.594.0843

[12] North, D.C. (1991) Institutions. The Journal of Economic Perspectives, 5, 97-112. https://doi.org/10.1257/jep.5.1.97

[13] Williamson, O.E. (1975) Markets and Hierarchies: Analysis and Antitrust Implications. A Study in the Economics of Internal Organization. Free Press, New York.

[14] Williamson, O.E. (1985) The Economic Institutions of Capitalism. Firms, Markets, Relational Contracting. Free Press, New York.

[15] Nielsen, B.B., Asmussen, C.G. and Weatherall, C.D. (2017) The Location Choice of Foreign Direct Investments: Empirical Evidence and Methodological Challenge. Journal of World Business, 52, 62-82. https://doi.org/10.1016/j.jwb.2016.10.006

[16] Azémar, A. and Desbordes, R. (2013) Has the Lucas Paradox Fully Explained. Economics Letters, 121, 183-187. https://doi.org/10.1016/j.econlet.2013.07.025

[17] Gertler, M. and Rogoff, K. (1990) North-South Lending and Endogenous Domestic. Journal of Monetary Economics, 26, 245-266. https://doi.org/10.1016/0304-3932(90)90022-V

[18] Montiel, P. (2006) Obstacles to Investment in Africa: Explaining the Lucas Paradox. The High-Level Seminar Realizing, the Potential for Profitable Investment in Africa.

[19] Ahearne, A.G., Griever, W.L. and Warnock, F.E. (2004) Information Costs and Home Bias: An Analysis of US Holdings of Foreign Equities. Journal of International Economics, 62, 313-336. https://doi.org/10.1016/S0022-1996(03)00015-1

[20] Vasileva, K. (2011) Foreign Direct Investment-A Behavioural Finance, London. Unpublished Thesis.

[21] Mendoza, E., Quadrini, V. and Rios-Rull, V. (2009) Financial Integration, Financial Deepness and Global. Journal of Political Economy, 117, 371-416. https://doi.org/10.1086/599706

[22] Odedokun, M. (2003) Analysis of Deviations and Delays in Aid Disbursements. Journal of Economic Development, 28, 137-169.

[23] Djahani, E. (2015) The Main Determinants of International Competitiveness in Sub-Saharan Africa. MPRA Paper.

[24] Ranciere, R., Tornell, A. and Westermann, F. (2008) Decomposing the Effects of Financial Liberalization: Crises vs. Growth. Journal of Banking \& Finance, 30, 33313348. https://doi.org/10.1016/j.jbankfin.2006.05.019

[25] Koudou, V. (2014) Analyse des determinants des IDE dans les pays de l'UEMOA. 
African Economic Research Consortium.

[26] Faria, A. and Mauro, P. (2004) Institutions and the External Capital Structure of Countries. Journal of International Money and Finance, 28, 367-391. https://doi.org/10.1016/j.jimonfin.2008.08.014

[27] Eichengreen, E. (2003) Capital Flows and Crisis. MIT Press, Cambridge. https://doi.org/10.7551/mitpress/1731.001.0001

[28] Prescott, E. (1998) Needed: A Theory of Total Factor Productivity. International Economic Review, 39, 525-552. https://doi.org/10.2307/2527389

[29] Dickey, D.A. and Fuller, W. (1979) A Distribution of the Estimators for Autoregressive Time Series with a Unit Root. Journal of the American Statistical Association, 74, 427-431. https://doi.org/10.1080/01621459.1979.10482531

[30] Maddala, G.S. and Wu, S. (1999) A Comparative Study of Unit Root Tests with Panel Data and a New Sample. Oxford Bulletin of Economics and Statistics, 61, 631-652. https://doi.org/10.1111/1468-0084.0610s1631

[31] Choi, I. (2002) Combination Unit Root Tests for Cross-Sectionally Correlated Panels.

[32] Levin, A. and Lin, C.F. (2002) Unit Root Test in Panel Data: Asymptotic and Finite Sample Properties. Journal of Econometrics, 108, 1-24. https://doi.org/10.1016/S0304-4076(01)00098-7

[33] Chang, Y. (2002) Nonlinear IV Unit Root Tests in Panels with Cross-Sectional Dependency. Journal of Econometrics, No. 110, 261-292. https://doi.org/10.1016/S0304-4076(02)00095-7

[34] Pesaran, M. (2003) A Simple Panel Unit Root Test in the Presence of Cross Section Dependence, Mimeo. University of Cambridge, Cambridge. https://doi.org/10.2139/ssrn.457280

[35] Moon, H. and Perron, B. (2004) Testing for Unit Root in Panels with Dynamic Factors. Journal of Econometrics, 122, 81-126. https://doi.org/10.1016/j.jeconom.2003.10.020

[36] Baltagi, B. (2012) Econometric Analysis of Panel Data. Wiley, Hoboken.

[37] Arrelano, M. and Bond, S. (1991) Some Tests of Specification for Panel Data: Monte Carlo Evidence and an Application to Employment Equations. Review of Economic Studies, 58, 277-297. https://doi.org/10.2307/2297968

[38] Blundell, N. and Bond, S. (1998) Initial Conditions and Moment Restrictions in Dynamic Panel Data Models. Journal of Econometrics, 87, 115-143. https://doi.org/10.1016/S0304-4076(98)00009-8

[39] Piteli, E. (2010) Determinants of Foreign Direct Investment in Developed Economies: A Comparison between European and Non-European Countries. Contributions to Political Economy, 29, 111-128. https://doi.org/10.1093/cpe/bzq004

[40] Cleeve, E. (2008) How Effective Are Fiscal Incentives to Attract FDI to Sub-Saharan Africa. The Journal of Developing Areas, 42, 135-153. https://doi.org/10.1353/jda.0.0015

[41] Lee, S. (2016) Geography of Cross-Border Portfolio Investments and ICT Diffusion. International Review of Economics and Finance, 45, 540-552. https://doi.org/10.1016/j.iref.2016.07.015

[42] Mhlanga, N., Blalock, G. and Christy, R. (2010) Understanding Foreign Direct Investment in the Southern African Development Community: An Analysis Based on Project-Level Data. Agricultural Economics, 41, 337-347. https://doi.org/10.1111/j.1574-0862.2010.00440.x 


\section{Appendix}

Table A1. List of countries in the sample by sub-region.

\begin{tabular}{ccc}
\hline Central and Western Africa & Southern and Eastern Africa & North Africa \\
\hline Benin & Botswana & Egypt \\
Burkina Faso & Kenya & Morocco \\
Burundi & Mozambique & \\
Central African Republic & Mauritius & \\
Congo & Namibia & \\
Ivory Coast & Tanzania \\
Cameroon & South Africa \\
Gabon & Zambia & \\
Mauritania & \\
Niger & \\
Nigeria & \\
Rwanda & \\
Senegal & \\
Sierra Leone & \\
Togo & \\
\hline
\end{tabular}

Table A2. Stationarity test of the variables.

\begin{tabular}{|c|c|c|c|c|c|c|}
\hline \multirow{2}{*}{$\begin{array}{c}\text { Tests } \\
\text { Variables }\end{array}$} & \multicolumn{3}{|c|}{ Levin et Lin (2002) } & \multicolumn{3}{|c|}{ Pesaran (2002) } \\
\hline & $\mathrm{P}$-value & $\begin{array}{c}\text { Type of } \\
\text { specification }\end{array}$ & $\begin{array}{c}\text { Order of } \\
\text { integration }\end{array}$ & P-value & $\begin{array}{c}\text { Type of } \\
\text { specification }\end{array}$ & $\begin{array}{l}\text { Order of } \\
\text { integration }\end{array}$ \\
\hline TFP & 0.00 & $\operatorname{lag}(2)$ & $\mathrm{I}(0)$ & 0.00 & $\operatorname{lag}(1)$ & $\mathrm{I}(0)$ \\
\hline LFDI & 0.00 & $\operatorname{lag}(2)$ & $\mathrm{I}(0)$ & 0.00 & $\operatorname{lag}(1)$ & $\mathrm{I}(0)$ \\
\hline QTI & 0.00 & $\operatorname{lag}(2)$ & $\mathrm{I}(0)$ & 0.07 & $\operatorname{lag}(1)$ & $\mathrm{I}(1)^{\star}$ \\
\hline d_QTI & 0.00 & $\operatorname{lag}(2)$ & $\mathrm{I}(0)$ & 0.00 & $\operatorname{lag}(1)$ & $\mathrm{I}(0)$ \\
\hline SIZ & 0.00 & $\operatorname{lag}(2)$ & $\mathrm{I}(0)$ & 0.00 & $\operatorname{lag}(1)$ & $\mathrm{I}(0)$ \\
\hline ICT & 0.99 & trend & $\mathrm{I}(2)^{*}$ & 1.00 & Trend & $\mathrm{I}(1)^{\star}$ \\
\hline d_ICT & 0.99 & trend & $\mathrm{I}(1)^{*}$ & 0.00 & Trend & $\mathrm{I}(0)$ \\
\hline OPE & 1.00 & Trend & $\mathrm{I}(1)^{\star}$ & 0.00 & Trend & $\mathrm{I}(0)$ \\
\hline d_OPE & 0.00 & $\operatorname{lag}(2)$ & $\mathrm{I}(0)$ & 0.00 & $\operatorname{lag}(1)$ & $\mathrm{I}(0)$ \\
\hline LCAP & 0.00 & $\operatorname{lag}(2)$ & $\mathrm{I}(1)^{\star}$ & 0.00 & $\operatorname{lag}(1)$ & $\mathrm{I}(0)$ \\
\hline d_LCAP & 0.00 & Trend & $\mathrm{I}(0)$ & 0.00 & $\operatorname{lag}(1)$ & $\mathrm{I}(0)$ \\
\hline NRES & 0.00 & $\operatorname{lag}(2)$ & $\mathrm{I}(0)$ & 0.01 & $\operatorname{lag}(1)$ & $\mathrm{I}(0)$ \\
\hline $\mathrm{HC}$ & 0.00 & trend et lag (3) & $\mathrm{I}(0)$ & 0.00 & $\operatorname{lag}(1)$ & $\mathrm{I}(0)$ \\
\hline RPR & 0.00 & Trend & $\mathrm{I}(0)$ & 0.00 & $\operatorname{lag}(1)$ & $\mathrm{I}(0)$ \\
\hline FD & 0.00 & $\operatorname{lag}(2)$ & $\mathrm{I}(0)$ & 0.00 & $\operatorname{lag}(1)$ & I $(0)$ \\
\hline GRO & 0.00 & $\operatorname{lag}(2)$ & $\mathrm{I}(0)$ & 0.00 & $\operatorname{lag}(1)$ & $\mathrm{I}(0)$ \\
\hline INF & 0.00 & $\operatorname{lag}(2)$ & $\mathrm{I}(0)$ & 0.00 & $\operatorname{lag}(1)$ & $\mathrm{I}(0)$ \\
\hline INV & 0.00 & lag (2) & I $(0)$ & 0.00 & Trend & I $(0)$ \\
\hline
\end{tabular}


Table A3. (a) Correlation table of variables in Africa; (b) Correlation test of variables for West and Central Africa.

(a)

\begin{tabular}{|c|c|c|c|c|c|c|c|}
\hline & LFDI & TFP & $\mathrm{HC}$ & D_ICT & OPE & D_OPE & INS \\
\hline LFDI & 1 & & & & & & \\
\hline TFP & $0.5245^{\star}$ & 1 & & & & & \\
\hline $\mathrm{HC}$ & $0.2911^{*}$ & $0.6742^{*}$ & 1 & & & & \\
\hline D_ICT & $0.2667^{*}$ & $0.2499^{\star}$ & $0.3548^{*}$ & 1 & & & \\
\hline OPE & 0.0014 & $0.2076^{*}$ & $0.3847^{*}$ & $0.1434^{*}$ & 1 & & \\
\hline D_OPE & -0.0272 & -0.0224 & -0.0347 & -0.1215 & 0.1098 & 1 & \\
\hline INS & 0.0417 & 0.0202 & $0.2531^{*}$ & 0.0891 & $0.2424^{*}$ & 0.0157 & 1 \\
\hline LCAP & $0.8041^{*}$ & $0.5215^{\star}$ & $0.4220^{\star}$ & $0.3820^{*}$ & -0.0842 & -0.0776 & 0.0472 \\
\hline INV & 0.0921 & 0.0101 & 0.0342 & 0.0073 & $0.3895^{*}$ & 0.1114 & $0.1992^{*}$ \\
\hline QTI & $0.2715^{*}$ & $0.5881^{\star}$ & $0.5361^{\star}$ & $0.1468^{*}$ & 0.0184 & -0.0075 & 0.1104 \\
\hline SIZ & $0.2815^{\star}$ & $0.6933^{*}$ & $0.8089^{*}$ & $0.4157^{\star}$ & $0.3079^{*}$ & 0.0031 & $0.3323^{*}$ \\
\hline INF & $0.1264^{*}$ & 0.1031 & 0.0356 & -0.0784 & -0.1078 & -0.0262 & -0.0243 \\
\hline NRES & 0.0281 & $0.1496^{\star}$ & -0.1179 & -0.0794 & 0.0667 & 0.0338 & $-0.2947^{\star}$ \\
\hline \multirow[t]{2}{*}{ DEV } & $0.4627^{*}$ & $0.3950^{\star}$ & $0.5298^{\star}$ & $0.3366^{*}$ & 0.1315 & 0.0233 & $0.3764^{*}$ \\
\hline & LCAP & INV & QTI & SIZ & INF & NRES & DEV \\
\hline LCAP & 1 & & & & & & \\
\hline INV & -0.0200 & 1 & & & & & \\
\hline QTI & $0.2609^{*}$ & -0.0404 & 1 & & & & \\
\hline SIZ & $0.3506^{*}$ & $0.1232^{\star}$ & $0.4066^{*}$ & 1 & & & \\
\hline INF & 0.0580 & -0.0661 & 0.0715 & -0.0307 & 1 & & \\
\hline NRES & $-0.1629^{*}$ & $0.1548^{*}$ & $-0.2152^{*}$ & 0.0144 & $0.1428^{*}$ & 1 & \\
\hline DEV & $0.5476^{\star}$ & 0.0561 & $0.3718^{*}$ & $0.5779^{*}$ & -0.0820 & $-0.2647^{\star}$ & 1 \\
\hline
\end{tabular}

(b)

\begin{tabular}{cccccccc}
\hline & LFDI & TFP & HC & D_ICT & D_OPE & INS & LCAP \\
\hline LFDI & 1 & & & & & & \\
TFP & $0.5392^{*}$ & 1 & & & & & \\
HC & $0.2603^{*}$ & $0.6534^{*}$ & 1 & & & & \\
D_ICT & $0.2187^{*}$ & $0.2444^{*}$ & $0.3590^{*}$ & 1 & & & \\
D_OPE & -0.1090 & -0.0618 & 0.0098 & $-0.1988^{*}$ & 1 & & \\
INS & 0.0570 & 0.0124 & 0.0969 & 0.0698 & 0.0537 & 1 & \\
LCAP & $0.8274^{*}$ & $0.5222^{*}$ & $0.3033^{*}$ & $0.3454^{*}$ & -0.1587 & $0.1541^{*}$ & 1 \\
INV & 0.0228 & 0.1386 & $0.1748^{*}$ & -0.0612 & 0.1599 & $0.2502^{*}$ & -0.0609 \\
QTI & -0.0980 & 0.0894 & $0.4101^{*}$ & 0.0560 & 0.0738 & $0.2164^{*}$ & -0.0210 \\
SIZ & $0.2615^{*}$ & $0.7734^{*}$ & $0.8651^{*}$ & $0.4238^{*}$ & -0.0017 & 0.1084 & $0.3134^{*}$ \\
INF & $0.2125^{*}$ & 0.1221 & 0.0302 & -0.0527 & -0.0208 & -0.0390 & 0.0696 \\
\hline
\end{tabular}




\begin{tabular}{|c|c|c|c|c|c|c|c|}
\hline Continue & & & & & & & \\
\hline NRES & $0.2152^{\star}$ & $0.4444^{\star}$ & $0.1571^{\star}$ & 0.0513 & 0.0089 & $-0.2051^{\star}$ & -0.0259 \\
\hline DEV & $0.1957^{\star}$ & 0.1078 & $0.2588^{\star}$ & 0.1260 & -0.0265 & $0.3313^{*}$ & $0.2759^{*}$ \\
\hline & INV & QTI & SIZ & INF & NRES & DEV & \\
\hline INV & 1 & & & & & & \\
\hline QTI & $0.2160^{*}$ & 1 & & & & & \\
\hline SIZ & $0.2260^{*}$ & $0.3011^{*}$ & 1 & & & & \\
\hline INF & -0.0252 & 0.0658 & 0.0359 & 1 & & & \\
\hline NRES & $0.2655^{\star}$ & $-0.2037^{\star}$ & $0.2954^{\star}$ & $0.1637^{\star}$ & 1 & & \\
\hline DEV & $0.3907^{\star}$ & $0.3615^{\star}$ & 0.0937 & -0.0976 & 0.0190 & 1 & \\
\hline
\end{tabular}

Table A4. (a) Normality test for the model (Africa); (b) Normality test for model2 (Central and West Africa).

(a)

\begin{tabular}{ccc}
\hline & Chi 2 & Prob (Chi 2) \\
\hline Joint test for Normality on $\mathrm{e}$ & 4.13 & 0.1266 \\
Joint test of Normality on $\mathrm{u}$ & 1.64 & 0.4397 \\
\hline & $(\mathrm{b})$ & \\
\hline Joint test for Normality on $\mathrm{e}$ & Chi 2 & Prob (Chi 2) \\
\hline Joint test of Normality on u & 5.63 & 0.0598 \\
\hline
\end{tabular}

